\title{
SHOPPING MOTIVATION IN CONSUMER LOYALTY FORMATION PROCESS: THE CASE OF SPANISH RETAIL
}

\author{
Sandra Tena-Monferrer ${ }^{1}$, Juan Carlos Fandos-Roig ${ }^{2}$, Javier Sánchez-García ${ }^{3}$, Luis Callarisa-Fiol ${ }^{4}$ \\ 1,2,3,4 Universitat Jaume I (Castellón de la Plana, Spain), smonferr@emp.uji.es, jfandos@emp.uji.es, \\ jsanchez@emp.uji.es, callaris@emp.uji.es
}

\begin{abstract}
Purpose: With the gradual decline of the small retail sector in the past recent years, few researchers have been addressing the issue from a motivational approach. This paper aimed to examine the role of utilitarian, hedonic and ethical motives in the process of forming consumer loyalty in a retail setting.
\end{abstract}

Design/methodology/approach: A total of 213 surveys were carried out among regular fashion and accessories shoppers in Spanish small-sized retailers. To test the model, a two-step methodology proposed by Anderson and Gerbing (1988) was applied.

Findings: Ethical shopping motivation was found to have the most relevant impact on its perceived quality and on its reassurance to a small-sized retailer, as it represented a strategic asset. Although the most appropriate approach would not be focused mainly on ethical aspects in order to be competitive in the new retailing landscape, consumers should recognize that they are contributing to a worthy cause while enjoying the shopping experience.

Practical implications: Small-sized retailers should provide consumers with good reasons for shopping in their businesses rather than their competitors'. Moreover, it is key to differentiate and build customer loyalty with the purpose of becoming more competitive. As a consequence, in this paper we propose a measurement scale that can be used to evaluate abstract and complex consumers' shopping motivation.

Originality/value: The pursuit of a more precise knowledge of factors that lead consumers to shopping a specific product is vital for small-sized retailers', towards a sustainable competitiveness. Here we analyzed the impact of the three innovative dimensions in shopping motivation on consumers' perceived quality and their influence on repurchase intention.

Keywords: Shopping motivation; Utilitarian motives; hedonic motives; Ethical motives; Perceived quality; Repurchase intention; Small-sized retailers 


\section{Introduction}

Over the last few years, the deterioration of small-sized retailers in urban centers has been observed in many countries such as France (Delage et al., 2020), Belgium (Grimmeau and Wayens, 2016) and Spain (Álvarez, et al., 2019). This decline is visible by walking through the main streets of any common city, where the drop in the number and diversity is becoming increasingly evident. These changes are a consequence of the retail sector transformation process, where small-sized retailers notices their presence reduced to the benefit of larger retailers, mostly located in the periphery and organized in shopping centers (Hallsworth and Coca-Stefaniak, 2018). Additionally, e-commerce is experiencing an exponential growth universally, and it is considered as an additional cause of the decline of physical trade, since consumers greatly value its convenience (Madan and Yadav, 2018).

In light of the above, it is important to highlight the significant role that small businesses play in the economy of cities, including strengthening social aspects (Coca-Stefaniak et al., 2010). In the peripheral areas, the competition between small and large commercial businesses has been confirmed through the deterioration of a sector that can hardly compete in terms of prices, opening times, offers, product assortment or personnel.

Urban retailers, like almost every small and medium commercial businesses, are facing an uncertain future. The economy has not been yet recovered from previous financial crisis and the impact of COVID-19 pandemic, which has changed the world in just three months, threatens to end with smallsized urban retailers. Therefore, it is necessary to shed light into shopping motives behind consumers' decisions, so marketing strategies can be developed in order to improve the competitiveness of small businesses (Parker and Wenyu, 2019).

In this regard, feelings prior to the purchase, as they represent shopping motives, can play a decisive role in this evaluation (Kumar and Kashyap, 2018). Shopping motivation, as understood from a cognitive, emotional and social perspective, can influence final consumers' quality perceptions. This way, it will be of great interest to study this relationship and to clarify the connections that form the process of quality evaluation.

Consequently, the objective of the present work is to deepen the knowledge of consumers' shopping motives by studying its utilitarian, hedonic and ethical dimensions. With the understanding of individuals' motivations and values, we expect to understand why individuals behave the way they do while shopping. In addition, we also studied the influence of shopping motives from a multidimensional perspective in the final evaluation of perceived quality and analyzed how it may determine future repurchase intention.

The relevance of shopping motives for retailers becomes evident when one considers the heterogeneous consumer's behaviour in developing shopping preferences (Mehta et al., 2014). Smallsized retailers need to provide consumers with good reasons for shopping in their stores rather than in their competitors' (Singh, 2018), while creating differentiation and store loyalty (Brïdson and Evans, 2004; Aw, 2019).

\section{Theoretical framework}

\section{Shopping motivation}


Consumer motivation indicates the starting point of the purchasing decision making process (Caber and Albayrak, 2016), which is a key element in the understanding the consumer's behavior. Therefore, we can delimit the study of consumer's motivation as a research that aims to deepen and defining factors that lead consumers to adopt a certain shopping behaviors (Cardoso and Pinto, 2010).

The term motivation was initially defined as a tendency to act, to trigger one or more consequences, as an activation towards the achievement of a certain objective. Later, it was defined as the appearance, direction and persistence of a certain behavior (Solomon, 2015). From then on, it endowed not only with capacity to generate action, but also with the ability to lead to the achievement of a goal. Therefore, motivation represents the beginning of a behavior-oriented state directed towards the accomplishment of an objective or ideal state (Hoffman, 2015). Motivation influences individuals' behavior through the stimulus and endowment of direction in their actions. This way, motivation could be understood as a predisposition towards a certain performance resulting from past experiences, environmental influences or even aspects such as individual characteristics.

With regards to the dimensionality of consumers shopping motivation, we have identified two main types of research. On the one hand, the most traditional research examines shopping motivation as a construct formed by two dimensions: utilitarian motivation and hedonic motivation (Bardhi and Arnould, 2005; Parker and Wenyu, 2019; Sramova and Pavelka, 2019).

The utilitarian dimension represents the most rational part of the motivational variable, taking both cognitive and functional aspects into account (Babin et al., 2004; Kim, 2006; Cardoso and Pinto, 2010). It focuses on the satisfaction of a functional or economic need (Babin et al., 1994), where purchases are compared with the performance of a task, and its value represented by their success or completion. Hedonic consumption has been defined as those facets of human behavior that relate to the multisensory, fantasy and emotive aspects surrounding the shopping act (Kang and Park-Poaps, 2010; Hashmi et al., 2020). The hedonic buying motives are similar to the utilitarian ones, with a difference noted in the nature of the "task" to be completed. Here, the goal is to experience fun, fantasy and sensory stimulation rather than an efficient and rapid achievement.

On the other hand, in the last years the importance of a new perspective related to the morality that surrounds the purchase has been increasing. This new dimension has been recently focused on several studies (Bezençon and Blili, 2010; Guiot and Roux, 2010; Monier and Bergés, 2016) in addition to the traditional dimensions already known, improving the outcomes of the motivational study of consumer shopping behavior.

The concept of ethical consumption (from the Greek root ethikos, whose meaning is "moral") is conceived as a consequence of movement for the environment and green consumption (Nicholls, 2002). The distinction between green consumption and ethical consumption is paramount, as ethical concerns represent a wider range of issues (Monier and Bergés, 2016) and therefore a more complex decision-making process for consumers. Ethical issues include features of sustainability, social awareness, fair trade, social and labor aspects, and general welfare in a society.

While a number of studies have examined consumer motivation from the bidimensional traditional approach (Bardhi and Arnould, 2005; Cardoso and Pinto, 2010; Freestone and McGoldrick, 2008), only a few have addressed this phenomenon from a multidimensional perspective (Bezençon and Blili, 2010; Guiot and Roux, 2010). The findings provide compelling evidence that consumer motivation is evolving into a more complex nature which requires new dimensions to be considered. 
Most traditional studies refer to different consumer segments according to the relevance of hedonic or utilitarian motives in their choices. However, some segments such as the second-hand markets or small-sized retailers are characterized by an unusual atmosphere or historical relevance. For example, traditional shops stablished in many cities for hundreds of years have been providing goods or services for numerous family generations.

Nowadays, we would not have a complete understanding of the motivational variable without including an ethical dimension. With a rising number of people identifying themselves as ethical consumers (Hughes, 2012), the study of their motivations is important to marketing researchers and practitioners. People are often able to give up on something to help others (Schoolman, 2016). In this research we will use this multidimensional perspective that considers shopping motivation to be formed by three dimensions: utilitarian, hedonic and ethical. We believe this perspective presents the best fit and offers the most complete vision of what occurs in the consumers' minds (Bardhi and Arnould, 2005; Freestone and McGoldrick, 2008; Bezençon and Blili, 2010; Cardoso and Pinto, 2010; Guiot and Roux, 2010; Monier and Bergés, 2016), also matching with the objective of our research.

\section{Theory of Reasoned Action (TRA)}

The relationship between attitude and behavior has been examined following the principles of the Theory of Reasoned Action (TRA) (Fishbein and Ajzen, 1980). Although this theory has its origin in the field of psychology, it has been the basis of a significant number of studies in marketing. In its basic formulation, TRA is composed of three general constructs: behavioral intention, attitude, and subjective norms. The theory suggests that an individual's behavioral intention depends on attitude and subjective norms. TRA states that human behavior is linked with the behavioral intention of any individual to carry out a certain action. Thus, we have introduced the central concept of the theory behavioral intention - which represents the ability to predict behavior based on attitude.

Attitude is based on the beliefs and evaluations on a specific element. Through personal experience, either by direct observation or by information received as a result of deductive processes, every individual has a set of beliefs about a given element. So, an element is associated with multiple attributes. The entirety of a person's beliefs is the basis for determining their attitude, intentions and behavior. It is, therefore, a rational approach in which individuals process the available information to make judgments, evaluations and decisions.

Furthermore, the model proposes subjective norms. This normative component refers to the influence of the social environment on the individual's behavior. The subjective norm is the individual's perception of the approval or disapproval of a specific action by its social environment. It is a subjective assessment of the individual on whether people believe they should perform a specific behavior or not. Therefore, subjective norms will influence one's behavioral intent as a normative component, which means that social approval is required to perform some actions.

Consequently, and considering that our objective is to analyze the formation of loyalty in a retail setting, we consider motivation similar to attitude. An aggregated number of experiences, opinions and beliefs determine behavioral intentions, such as repurchase intention. Therefore, the TRA represents the theoretical framework that will guide us to understand the consumers' behavior. 


\section{Perceived quality}

Service quality is a key aspect in explaining individual's shopping behavior (Khorshidi et al., 2016). This can become an important element in drawing new clients in, especially for companies with limited economic capacity (Kajenthiran, 2018).

Therefore, as widely discussed in the marketing literature, service quality represents a significant variable when it comes to retaining clients (Moreo et al., 2019). However, quality is not a purely an objective element, since it depends on the individual's perceptions on several aspects that affect the final quality assessment (attributes, product, atmosphere elements or personnel) (Fan et al., 2017).

Consumer perceived quality has been identified as one of the main aspects influencing consumer's final purchase intention (Wang, 2013; Rezaei et al., 2014). According to Parasuraman et al. (1988), perceived quality can be defined as the difference between expected service (consumer expectations) and perceived service (consumer perceptions). This way, several studies have concluded that perceived quality is subjective and comparative in nature, as it represents the consumers' judgements (Prebensen and Xie, 2017).

SERVQUAL (Parasuraman et al., 1988) and SERVPERF (Cronin and Taylor, 1992) were found to be the most employed measurement scales for perceived quality. SERVQUAL measures consumers' perceptions and assumes that these perceptions of service quality are directly compared with the expectations previously generated. SERVPERF, however, being identical in dimensions and structure to the previous one, only measures perceptions. In both scales we find authors who find weaknesses related to their dimensionality, which presents variations depending on the industry in which it is applied (Erdil and Yildiz, 2011).

The discussion on SERVQUAL or SERVPERF for measuring perceived service quality in retail settings (Koelemeijer, 1993) and the methodological disadvantages implied by the inferred disconfirmation suggests the relevance of considering an alternative model for measuring perceived service quality.

We applied the evaluation of consumers' perceived result in the present study, as the question to be analyzed was related to the extent different shopping motives influenced consumers' perceived quality.

Motivation is an emotional state that will condition the individual's quality perception (Frías-Jamilena et al., 2019). As shopping motives, in general, are considered as inner drives that cause people to take action to satisfy their needs, a greater shopping motivation will favor a better quality perception.

Consumers with different shopping motivations evaluate not only perceived quality differently but also other variables such as satisfaction or loyalty (Chakraborty and Soodan, 2019). The influence of shopping motives on perceived quality is assumed by many retail researchers (Das, 2014) and thus, we will also take it into account.

An individual with a greater hedonic motivation towards shopping, understanding of a greater predisposition to enjoyment and sensory experimentation, will lead to a higher perceived quality, as we are facing a subjective perception of the individual (Wang, 2017; Blinda et al., 2019). Fun intrinsically motivates people to engage in an activity, so the perception of fun creates a value by itself, regardless of the potential outcome. Thereby, we present the first hypothesis: 
H1. Hedonic shopping motivation directly and positively influences perceived quality.

Utilitarian motivation represents the most cognitive dimension of the motivational variable. This type of motivation leads individuals to perceive purchases as tasks or functional problems to be solved. The purchases would be directly related to an efficient and rational decision making. Utilitarian motives are related to utility, functionality and simple performance. Task completion will lead individuals to a greater predisposition to positively value perceived quality (Wang, 2017; Blinda et al., 2019). Hence, we present the second hypothesis:

H2. Utilitarian shopping motivation directly and positively influences perceived quality.

Any individual at any given time feels the need to do good. Ethically motivated consumers perceive small-sized retailers as an alternative consumption (Davies and Gutsche, 2016). It is a way in which the individual feels good by helping others or contributing to the local environment. Furthermore, they can perceive benefits such as an accomplishment or peer esteem. Perceived quality can also be influenced by this moral cause. By conducting a particular shopping act, an individual may feel good through contributing to the environment and the economy. In that sense, ethically motivated consumers will be more willing to perceive higher quality through their own feeling of doing what is correct (Nassivera and Sillani, 2015). Thus, it is expected that a higher quality of the transaction is perceived by the fact of helping others, and hence we present the third hypothesis:

H3. Ethical shopping motivation directly and positively influences perceived quality.

\section{Repurchase intention}

It is a very complex task to predict consumers' behaviour, but the most accurate variable we can make is the use of is purchase intention (Chang et al., 2019). Purchase intention influences the end result of the purchase behavior. There are several studies that have determined that repurchase intention represents the final observed behavior to a great extent (Lin, et. al., 2014).

Consumers' preferences to shop in terms of purchase behavior and attitude, forms loyalty (Wang, et. al., 2012). Accordingly, Oliver (1999) defined loyalty as "a deeply held commitment to re-buy or repatronize a preferred product/service consistently in the future, thereby causing repetitive same-brand or same brand-set purchasing". Thus, the variable is commonly defined as a consumer's intention or predisposition to purchase again from the same organization (Rauyruen and Miller, 2007). In fact, the retention of loyal customers has been shown to be more important than acquiring new ones in recent years.

From a deterministic point of view, loyalty is conceptualized as an attitude or an intention to repurchase. Research in this scope provides a better knowledge on how to create loyalty and keep customers loyal to a particular brand. 
Repurchase intention is the individual's judgment on repeating the same shopping act in the same firm. The reason why customers decide to select the same service provider and purchase the same service or product is based on their previous experiences, and it involves an individual's judgment on that specific firm, which is known to satisfy its needs.

At this point it is noticeable that repurchase intention represents a widely applied indicator in loyalty literature, being understood as an antecedent of the very own purchase action (Wang, et. al., 2012; Lin, et. al., 2014).

Perceived quality is one of the most relevant factors influencing the consumers repurchase intention (Das, 2014; Wang 2017; Rahman et al., 2018). Product's quality perception is associated with the tendency of store patronization (Pan and Zinkhan, 2006). In other words, perceived quality positively correlates with purchase intention. Specifically, authors have found a positive relation between perceived quality and repurchase intention in retail settings (Vajarodaya and Fernando, 2017).

Given all the aforementioned evidence (Wu and Chen, 2014; Wang 2017; Mazlan et al., 2016; Vajarodaya and Fernando, 2017; Rahman et al., 2018), we postulate the following hypothesis:

H4. Perceived quality directly and positively influences repurchase intention.

In order to illustrate the hypotheses, we present a theoretical framework that will serve as a reference for this study (Figure 1 - Theoretical framework).

\section{Research design and methods}

In order to achieve the proposed objectives and to test the hypotheses, a quantitative research was conducted with a total of 213 personal face-to-face personal interviews through a structured questionnaire. The research was designed to guide the interviewees to reflect on their last purchasing process in small-sized fashion and accessories retailers. We explained the meaning of the fundamental purchasing terminology at the beginning of the interview.

The employed measurement scales are derived from previous studies, adapted to the characteristics of the present research. A structured questionnaire was used with closed questions valued by a 5point Likert scale where $1=$ totally disagree and $5=$ totally agree. The scales measured shopping motivation and perceived quality based on the items proposed by Kim (2006), Cardoso and Pinto (2010) and Guiot and Roux (2010), and Sweeney and Soutar (2001) and Sánchez et al. (2006) respectively. The items for repurchase intention were based on Caruana (2002) and Fandos et al. (2013).

An initial pretest of the questionnaire was carried out on 25 people. The correct understanding of the questions was verified and some improvements were made based on the results. In addition, we performed a series of correlation analyses, reliability tests and exploratory factor analyses for each construct, to verify the psychometric capacity of the measurement scales. Lastly, the final version of the questionnaire was obtained. 


\section{Spanish retail sector}

Retail trade is one of the most important activities in the Spanish economy, representing $40 \%$ of the total sales in the sector. The small-sized retailer is one of the most important economic agents in this segment, represented mostly by sole proprietorships and less than three employees. They represent a key part of the national productive structure, not only because of the generation of GDP, but also due to its participation in the labor market, contributing positively to the occupation rates and job creation.

Spain have been showing an increased number of new businesses, with $20 \%$ being less than 2 years old and $55 \%$ with no employees (INE, 2018). This confirms a tendency to start new businesses in response to times of crisis. However, the sector is fragile as constantly being exposed to economic, social and technological fluctuations, with an average of 25 small businesses closures every day.

As a consequence, a carefully designed sampling method was implemented in order to guarantee the representativeness of the sample. The field work was carried out by independent professional interviewers to 213 respondents, regular shoppers in small-sized fashion and accessories retailers. The surveys were conducted in the provinces of Castellón and Valencia. Stratification criteria were established according to location, gender and age of the respondents. The Spanish population pyramid report, which is based on the 2019 population census data provided by the Spanish National Statistics Institute (INE), was taken as a reference. Table 1 demonstrates the proportionality of the sample. Sampling error was of $6.85 \%$.

The selection of the Spanish provinces of Castellón and Valencia as a universe of study responds to a series of factors related to their commercial and industrial nature. First, according to INE's data, 94 $\%$ of the businesses in these provinces are considered small. A small business has less than 50 employees and its annual turnover does not exceed 10 million euros. In addition, according to the same source, the production of the fashion and accessories textile sector represented in 2019 approximately a quarter of the total Spanish production. Valencia is a large area of tourist influx while Castellón, although also receiving a large volume of tourists, is a city with an industrial character. Thus, the use of small businesses in the provinces of Castellón and Valencia in our study is suitable as it contrasts with the theoretical model proposed in the previous section.

Based on these responses, a process of purification was carried out in order to identify and eliminate atypical cases. Table 1 shows the main characteristics of the samples obtained in the present study. Broadly, there were approximately half men and women, representing all age groups.

The educational level of the analyzed sample was generally quite high. As for the total monthly household income, $20.2 \%$ of the individuals in the sample had an income up to 1,000 euros, while $40.8 \%$ had between 1,001 and 1,500 euros per month, $31.5 \%$ between 1,501 and 2,500 euros, and only $7.5 \%$ more than 2,500 euros per month. As for the occupational status, most of the interviewees worked $(53.5 \%)$, while a significant proportion were unemployed $(20.2 \%)$. In addition, the sample had a good representation of students, homemaking and retirees. In general terms, we can state that it was a representative sample of the Spanish population, being adequate for our study.

\section{Analysis and results}

To test the proposed model in small-sized retailers, we opted for a two-step methodology proposed by Anderson and Gerbing (1988), on the basis of the number of comparative advantages that allow 
meaningful inferences to be made in comparison to one-step approaches. Besides, it permits significance tests for all pattern coefficients to be carried out, also providing a convenient framework for formal comparisons.

The proposed theoretical model was tested by means of structural equation modelling (SEM) using Lisrel 8.80 statistical software. This analytical methodology helped to estimate the effect and relationships between multiple variables. It also allowed to relate observed variables with latent factors in the confirmatory factor analysis. Furthermore, in the analysis of the structural model, latent variables could be related to each other (Jöreskog and Sörbom, 1996).

The variables in the model are of a reflective nature, according to the criteria offered by Jarvis et al. (2003). Thus, in order to validate the measurement scales, our model analyzed their dimensionality, validity and reliability. The first stage was to determine the quality of the measurement scales. It was performed by a confirmatory factor analysis with all scales together. The second step was to contrast conceptual model relationships. This approach allowed us to maximize the performance of both the quality of the measurement scale and the results obtained from relationships raised in the conceptual model.

Common method variance (CMV) is known to inflate or deflate the correlations between constructs, if these constructs are measured using the same method and at the same moment in time. There is therefore a possibility in which common method bias (Podsakoff et al., 2003) may have been introduced. To control this effect, the Harman Single Factor test was performed and the results obtained ensured that there was no evidence of common method bias in our data (Harman, 1960; MacKenzie and Podsakoff, 2012).

\section{a. Scale validation}

Firstly, a study of the dimensionality, reliability and validity of the measurement scales (Table 2 Analysis of scale dimensionality, reliability and validity) was carried out. The convergent validity was verified in two ways. On one hand, the factor loads were all significant and above 0.5 (Bagozzi and $\mathrm{Yi}, 1988$ ). On the other hand, the average extracted variance (AVE) for each factor was higher than 0.5 (Fornell and Larcker 1981). The reliability of the scale was demonstrated, as the composite reliability index of each dimensions obtained for all cases was higher than 0.6 (Bagozzi and Yi, 1988). In addition, the measurement model represented a good fit, with all reference index within the acceptance zones (Anderson and Gerbing, 1988). Thus, a probability associated with chi-squared higher than 0.05 (0.11207), CFI (0.99) and NNFI (0.99) near unity and RMSEA very close to 0 (0.031) were obtained.

Table 3 shows the discriminant validity of the variables, which were verified using the AVE (Fornell and Larcker, 1981). Therefore, a variable must have shared more variance in its indicators than with the rest of the variables. This occurs when the square root of the AVE between each pair of factors is higher than the estimated correlation between these factors. In this case, this confirmed its discriminant validity. As a result, the good quality of the measuring scales used was checked. 


\section{b. Analysis of the obtained structural model}

To test H1-H4 hypotheses, an analysis of the causal relationships for the total sample was conducted (Table 4 - Results of the structural model). This approach was adequate, as the probability of chisquare was higher than 0.05 (0.09800), CFI (0.98) and NNFI (0.98) and close to unity and RMSEA was close to zero $(0.055)$.

The value of the parameters in all cases was positive and significant ( $t$ higher than 1.96). Based on the result of the analysis performed, the four relationships proposed in the theoretical model were confirmed.

Firstly, we verified that hedonic shopping motivation (H1), utilitarian shopping motivation (H2) and ethical shopping motivation (H3) had a significant direct and positive effect on perceived quality. The direct and positive relationship between perceived quality and repurchase intention (H4) was also confirmed.

In addition to the direct effects analyzed above, it was also important to analyze the indirect ones, which together determined the total influence of one variable on another (Table 5 - Total and indirect effects). For instance, hedonic shopping motivation directly influenced perceived quality (0.22). Besides, we could also conclude that hedonic shopping motivation indirectly influenced repurchase intention through perceived quality $(0.22 * 0.88=0.19)$.

From the analysis of the intensity of the total effects, it was determined that perceived quality exercised the most intense influence on repurchase intention (0.88). In addition, the entire load of this relationship was projected directly. Secondly, we analyzed to what extent the dimensions of shopping motivation influenced perceived quality directly and repurchase intention indirectly through perceived quality. Ethical shopping motivation was the dimension with the highest load (0.46) on perceived quality, followed by utilitarian shopping motivation (0.34) and hedonic shopping motivation (0.19). In the same order, they influenced the evaluation of these three dimensions on repurchase intention. In this case the influence was indirect in all cases, through perceived quality.

\section{Discussion}

\section{Theoretical contributions}

Consumer shopping motivation has been widely studied in the literature as a construct formed of two dimensions. On the one hand, the utilitarian dimension represents the most rational part of the variable, collecting cognitive and functional aspects. It is focused on the satisfaction of a functional or economic need. On the other hand, the hedonic dimension includes facets of human behavior that relate to the multisensory, fantasy and emotional aspects that surround the shopping act.

However, the rising number of ethical consumers leads to include issues such as fair trade, labor standards, working conditions, economic and health conditions or animal, among others in any motivational study. Additionally, according to Freestone and McGoldrick (2008), it is desirable to include this ethical dimension in the measurement of the motivational variable, in order to obtain a more complete vision of what leads consumers to conduct a determinate shopping act. 
Besides, perceived quality represents the consumer's subjective evaluation of what they perceive compared to what they expected. In this subjectivity, perceived quality influences individuals' predisposition towards the purchasing behavior — shopping motivation. A greater shopping motivation should correspond to higher levels of perceived quality. This has been revealed in this research, in all its dimensions.

The proposed small-sized retailers shopping motivation measurement scale captures the variety of motives that underlie this specific form of retailers, in a context of post-financial crisis with a rising emergence of peripheral shopping centres and online shopping. Thus, our contribution incorporates three dimensions of motivation, enriching previous studies with the addition to the utilitarian and hedonic motive of an underlying factor that has not been measured before, namely, the ethical dimension. This critical approach is key, as concerns of the impact of shopping in large retailers on the environment and the local economy rise.

H1 is confirmed as hedonic shopping motivation influences, in a direct and positive way, consumers' perceived quality. Fun intrinsically motivates people to engage in an activity, so the perception of fun create value by itselves, regardless of the potential outcome. A greater predisposition to enjoyment and sensory experimentation leads to a higher perceived quality. In urban areas, consumers enjoy walking through the city center, with main streets full of shops and different stimuli. At the same time, consumers can set conversation with traders and meet friends and family in the surroundings.

Our next hypothesis is also confirmed as utilitarian shopping motives also directly and positively influence perceived quality (H2). Utilitarian motivation represents the most cognitive dimension as, by achieving the "shopping trip" objective, individuals will positively value perceived quality. Consumers accept that small retailers cannot compete in price with larger retailers, however they also value being able to get good opportunities in terms of value for money. Also, parking facilities or other options can positively contribute to the access to these shops.

$\mathrm{H} 3$ is confirmed as ethical shopping motivation directly and positively influences perceived quality. Ethically motivated consumers are more willing to perceive higher quality through their own feeling of doing what is correct. Shopping in small-sized retailer is considered a good formula to contribute to the local economy. Most Spanish small-sized retailers marketing campaigns are based on the idea that shopping at small retailers is investing in quality of life, as money spent in local shops stays in the same neighborhood, being translated into local economic growth and employment opportunities.

Comparing all the dimensions, it is the ethical one that showed the strongest influence on perceived quality, followed by the utilitarian and finally the hedonic motives. As a consequence, individuals positively appreciate making a good act through their contribution in a certain shopping act. Secondly, utilitarian motivation brings practical benefits to the consumer. And finally, hedonic motivation contributes to the individual's emotional and enjoyable experience.

While shopping, the feeling of "I am doing what is correct" in the ethically motivated consumer's mind is activated. However, for twenty-first's century consumers, a wider range of aspects should be covered in order to achieve store loyalty. Customers request pleasure, parking facilities, originality, sensory stimuli, surprise, the latest products and services, multiple channels to do shopping, and others. According to the literature, this research supports the emergence of the ethically-motivated consumer as an alternative to the traditional hedonic and utilitarian ones.

Small-sized retailers are characterized by having a limited product assortment, to be located in residential areas and to establish closer relations to consumers than other retail formats. It is therefore 
reasonable to assume that they are perceived as more traditional than other direct competitors. Consumers empathize more with this type of business as they are more likely to activate affective states such as ethical motivation. Bigger retailing formats with physical stores, as shopping malls, can compete on hedonic and utilitarian factors, as their coordination and sales volume allow them to obtain benefits as free parking in the same building or big marketing campaigns.

Finally, as mentioned above, given that perceived quality is shown as a strong antecedent of repurchase intention ( $\mathrm{H} 4)$, it can be said that motivation has an indirect influence on repurchase intention through perceived quality. Therefore, it is very important for small retailers to be able to work with consumers' shopping motivation.

All things considered, small urban businesses must be aware of the ethical nature of their format and its consequences. Knowing how to work correctly on ethical aspects, at first, and reinforce utilitarian and hedonic aspects is key to keep long term loyalty relations with consumers. Implementing actions and tools aimed at keeping up-to-date with trends in the fashion industry, analyzed in this study, would result in a very appropriate strategy.

\section{Managerial implications}

In a more practical sense, small businesses can carry out a set of actions that can lead to the stimulation of their ethical values without neglecting the hedonic and utilitarian aspects. Efforts should be made to develop trust and positive environmental attitudes towards their business, by sponsoring local initiatives or events. It would be important to reinforce small-sized retailers' ethical nature to enhance purchasing behaviour. This could also be achieved through the development of effective communication strategies focused on improving consumers' knowledge on how small-sized retailers underpin the development of neighborhoods and cities, as well as employment. Therefore, more effort can be made into communicating their ethical practices, pricing, product quality, and store management. Small-sized retailer's overall strategy should be focused on enhancing issues such as fair price, fair salaries, and sustainability in the distribution systems.

These actions should be aimed at highlighting the impact of this final shopping behaviour, inviting a reflection on which retailing option to choose. We are facing a scenario where it is essential to ask ourselves about the consumption model and city model that we want. Small-sized retailers are essential in communicating how the consumption model can enhanced.

It should also be considered that physical stores are the central asset for small-sized retailers located in the main streets of our cities, since it is where direct contact with the customer takes place. Physical locations should both minimize time and effort and maximize enjoyment when shopping. And since convenience is becoming such a relevant aspect, innovation in shopping experience should be developed across digital and physical channels, ensuring both hedonic and utilitarian motives are addressed.

\section{Limitations and further research}

Working on cross-section data while studying dynamic variables that can vary over time is a limitation of this study. Consequently, the results of this research are focused on the small-sized retail sector of fashion and accessories with physical store. It would be interesting to compare the results in other sectors, as fashion and accessories sector is commonly recognized as a highly hedonic one. 
For instance, it would be interesting to analyze the same model in the food and beverage sector, as it is expected to have a higher utilitarian load. Our study also focuses on the case of Spanish retail. It would be interesting to be able to replicate the same study in another country or culture to assess and compare results.

As future research, we aim to investigate whether different results can be found within retailing in comparison to the different types of retailers. In addition, another series of variables such as satisfaction and trust can be introduced to complete a model of formation of repurchase intention. Furthermore, it would be interesting to know to what extent this can be applied to the online context.

\section{References}

Álvarez, C., Martín, M. and Iribarren, D. (2019), "Sustainability-oriented management of retail stores through the combination of life cycle assessment and dynamic data envelopment analysis", Science of the Total Environment, Vol. 683, pp. 49-60. DOI: 10.1016/j.scitotenv.2019.05.225.

Anderson, J.C. and Gerbing, D.W. (1988), "Structural equation modelling in practice: a review and recommended two-step approach", Psychological Bulletin, Vol. 103 No. 3, pp. 411-423. DOI: 10.1037/00332909.103.3.411.

Aw, E.C. (2019), "Understanding the webrooming phenomenon: shopping motivation, channel-related benefits and costs", International Journal of Retail \& Distribution Management, Vol. 47 No. 10, pp. 10741092. DOI: 10.1108/IJRDM-01-2019-0026.

Babin, B.J., Chebat, J.C. and Michon, R. (2004), "Perceived appropriateness and its effect on quality, affect and behavior", Journal of Retailing and Consumer Services, Vol. 11 No. 5, pp. 287-298. DOI: 10.1016/j.jretconser.2003.09.002.

Babin, B.J., Darden, W.R. and Griffin, M. (1994), "Work and/or fun: measuring hedonic and utilitarian shopping value", Journal of Consumer Research, Vol. 20 No. 4, pp. 644-656. DOI: 10.1086/209376.

Bagozzi, R.P. and Yi, Y. (1988), "On the evaluation of structural equation models", Journal of the Academy of Marketing Science, Vol. 16 No. 1, pp. 74-94. DOI: 10.1007/BF02723327.

Bardhi, F. and Arnould, E.J. (2005), "Thrift shopping: combining utilitarian thrift and hedonic treat benefits", Journal of Consumer Behaviour, Vol. 4 No. 4, pp. 223-233. DOI: 10.1002/cb.12.

Bezençon, V. and Blili, S. (2010), "Ethical products and consumer involvement: what's new?", European Journal of Marketing, Vol. 44 No. 9, pp. 1305-1321. DOI: 10.1108/03090561011062853.

Blinda, K., Schnittka, O., Sattler, H. and Gräve, J.F. (2019), "Implementing effective customer participation for hedonic and utilitarian services", Journal of Services Marketing, Vol. 33 No. 3, pp. 316-330. DOI: 10.1108/JSM-07-2018-0196.

Brïdson, K. and Evans, J. (2004), "The secret to a fashion advantage is brand orientation", International Journal of Retail \& Distribution Management, Vol. 32 No. 8, pp. 403-411. DOI: 10.1108/09590550410546223.

Caber, M. and Albayrak, T. (2016), "Push or pull? Identifying rock climbing tourists' motivations", Tourism Management, Vol. 55, pp. 74-84. DOI: 10.1016/j.tourman.2016.02.003. 
Cardoso, P.R. and Pinto, S.C. (2010), "Hedonic and utilitarian shopping motivations among Portuguese young adult consumers", International Journal of Retail \& Distribution Management, Vol. 38 No. 7, pp. 538-558. DOI: $10.1108 / 09590551011052124$.

Caruana, A. (2002), “Service loyalty”, European Journal of Marketing, Vol. 36 No. 7/8, pp. 811-828. DOI: $10.1108 / 03090560210430818$.

Chakraborty, S. and Soodan, V. (2019), "Examining utilitarian and hedonic motivations in online shopping in India: moderating effect of product browsing behavior", International Journal of Recent Technology and Engineering, Vol. 8 No. 1C2, pp. 117-125.

Chang, K. C., Hsu, C.L., Chen, M.C. and Kuo, N.T. (2019), "How a branded website creates customer purchase intentions", Total Quality Management and Business Excellence, Vol. 30 No. 3-4, pp. 422-446. DOI: 10.1080/14783363.2017.1308819.

Coca-Stefaniak, J.A., Parker, C. and Rees, P. (2010), "Localisation as a marketing strategy for small retailers", International Journal of Retail \& Distribution Management, Vol. 38 No. 9, pp. 677-697. DOI: 10.1108/09590551011062439.

Cronin, J.J. and Taylor, S.A. (1992), "Measuring service quality: a reexamination and extension", Journal of Marketing, Vol. 56 No. 3, pp. 55-68. DOI: 10.2307/1252296.

Das, G. (2014), "Linkages of retailer awareness, retailer association, retailer perceived quality and retailer loyalty with purchase intention: a study of Indian food retail brands", Journal of Retailing and Consumer Services, Vol. 21 No. 3, pp. 284-292. DOI: 10.1016/j.jretconser.2014.02.005.

Davies, I.A. and Gutsche, S. (2016), "Consumer motivations for mainstream "ethical" consumption", European Journal of Marketing, Vol. 50 No. 7-8, pp. 1326-1347. DOI: 10.1108/EJM-11-2015-0795.

Delage, M., Baudet-Michel, S., Fol, S., Buhnik, S. and Hadrien-Commenges, J.V. (2020), "Retail decline in France's small and medium-sized cities over four decades. Evidences from a multi-level analysis", Cities, Vol. 104 No. 102790, DOI: 10.1016/j.cities.2020.102790.

Erdil, S.T. and Yildiz, O. (2011), "Measuring service quality and a comparative analysis in the passenger carriage of airline industry", Procedia - Social and Behavioral Sciences, Vol. 24, pp. 1232-1242. DOI: 10.1016/j.sbspro.2011.09.117.

Fan, L.H. et al. (2017), "Patients' perceptions of service quality in China: An investigation using the SERVQUAL model”, PLoS ONE, Vol. 12 No. 12. DOI: 10.1371/journal.pone.0190123.

Fandos, J.C., Sánchez, J., Moliner, M.A. and Llorens, J. (2006), "Customer perceived value in banking services", International Journal of Bank Marketing, Vol. 24 No. 5, pp. 266-283. DOI: $10.1108 / 02652320610681729$.

Fishbein, M. and Ajzen, I. (1980). Understanding attitudes and predicting social behaviour. Englewood Cliffs, NJ: Prentice-Hall.

Fornell, C. and Larcker, D. F. (1981), "Evaluating structural equation models with unobservable variables and measurement error", Journal of Marketing Research, Vol. 18 No. 1, pp. 39-50. DOI: $10.1177 / 002224378101800104$.

Freestone, O. M. and McGoldrick, P. J. (2008), "Motivations of the ethical consumer", Journal of Business Ethics, Vol. 79 No. 4, pp. 445-467. DOI: 10.1007/s10551-007-9409-1.

Frías-Jamilena, D. M., Castañeda-García, J.A. and Del Barrio-García, S. (2019), "Self-congruity and motivations as antecedents of destination perceived value: the moderating effect of previous experience", International Journal of Tourism Research, Vol. 21 No. 1, pp. 23-36. DOI: 10.1002/jtr.2238.

Grimmeau, J. and Wayens, B. (2016), "Les causes de la disparition des petits commerces (1945-2015)", Courrier Hebdomadaire du Crisp, Vol. 16-17, pp. 5-114. DOI: 10.3917/cris.2301.0005. 
Guiot, D. and Roux, D. (2010), “A second-hand shoppers' motivation scale: antecedents, consequences, and implications for retailers", Journal of Retailing, Vol. 86 No. 4, pp. 355-371. DOI: 10.1016/j.jretai.2010.08.002.

Hallsworth, A. and Coca-Stefainak, J.A (2018), "National high street retail and town centre policy at a cross roads in England and Wales", Cities, Vol. 79, pp. 139-140.

Harman, H. H. (1960), Modern factor analysis, University of Chicago Press, Chicago.

Hashmi, H.B.A, Shu, C. and Haider, S.W. (2020), "Moderating effect of hedonism on store environmentimpulse buying nexus", International Journal of Retail \& Distribution Management, Vol. 48 No. 5, pp. 465483. DOI: 10.1108/IJRDM-09-2019-0312

Hoffman, B. (2015), Motivation for Learning and Performance, Motivation for Learning and Performance, Academic Press. DOI: 10.1016/C2013-0-18335-3.

Hughes, A. (2012), "Corporate Ethical Trading in an Economic Downturn: Recessionary pressures and refracted responsibilities", Journal of Economic Geography, Vol. 12 No.1, pp. 33-54.

Jarvis, C.B., MacKenzie, S.B. and Podsakoff, P.M. (2003), "A critical review of construct indicators and measurement model misspecification in marketing and consumer research", Journal of Consumer Research, Vol. 30 No. 2, pp. 199-218. DOI: 10.1086/376806.

Jöreskog, K.G. and Sörbom, D. (1996), LISREL 8: user's reference guide (2nd Edition), Scientific Software International.

Kajenthiran, K. (2018), “An empirical investigation on retail service quality and its impact on customer loyalty in the supermarkets in Jaffna District, Sri Lanka", Advances in Management \& Applied Economics, Vol. 8 No. 1, pp. 17-36.

Kang, J. and Park-Poaps, H. (2010), "Hedonic and utilitarian shopping motivations of fashion leadership", Journal of Fashion Marketing and Management, Vol. 14 No. 2, pp. 312-328. DOI: 10.1108/13612021011046138.

Kelley, S.W. and Turley, L.W. (2001), "Consumer perceptions of service quality attributes at sporting events", Journal of Business Research, Vol. 54 No. 2, pp. 161-166. DOI: 10.1016/S0148-2963(99)00084-3.

Khorshidi, H.A., Nikfalazar, S. and Gunawan, I. (2016), "Statistical process control application on service quality using SERVQUAL and QFD with a case study in trains' services", The TQM Journal, Vol. 28 No. 2, pp. 195-215. DOI: 10.1108/TQM-02-2014-0026.

Kim, H. (2006), "Using hedonic and utilitarian shopping motivations to profile inner city consumers", Journal of Shopping Center Research, Vol. 13 No. 1, pp. 57-79.

Koelemeijer, K. (1993), "Perceived quality of retail services: an exploratory investigation of an alternative model”, European Advances in Consumer Research, Vol. 1, pp. 322-328.

Kumar, A. and Kashyap, A.K. (2018), "Leveraging utilitarian perspective of online shopping to motivate online shoppers", International Journal of Retail \& Distribution Management, Vol. 46 No. 3, pp. 247-263. DOI: 10.1108/IJRDM-08-2017-0161.

Lin, Y.H., Lin, F.J. and Ryan, C. (2014), "Tourists' purchase intentions: impact of franchise brand awareness", Service Industries Journal, Vol. 34 No. 9-10, pp. 811-827. DOI: 10.1080/02642069.2014.905919.

MacKenzie, S.B., and Podsakoff, P.M. (2012), "Common Method Bias in Marketing: Causes, Mechanisms, and Procedural Remedies", Journal of Retailing, Vol. 88 No. 4, pp. 542-555.

Madan, K. and Yadav, R. (2018), "Understanding and predicting antecedents of mobile shopping adoption: a developing country perspective", Asia Pacific Journal of Marketing and Logistics, Vol. 30 No. 1, pp. 139162. 
Mazlan, S., Ariffin, S., Aziz, Z.D. and Yusof, J.M. (2016), "Factors affecting purchase intention of Iphone among business students in UiTM Puncak Alam, Selangor', International Academic Research Journal of Business and Technology, Vol. 2 No. 2, pp. 57-62.

Mehta, R.K. Sharma, N. and Swami, S. (2014), "A typology of Indian hypermarket shoppers based on shopping motivation", International Journal of Retail \& Distribution Management, Vol. 42 No. 1, pp. 40-55. DOI: 10.1108/IJRDM-06-2012-0056.

Monier-Dilhan, S. and Bergés, F. (2016), "Consumers' motivations driving organic demand: between selfinterest and sustainability", Agricultural and Resource Economics Review, Vol. 45 No. 3, pp. 522-538. DOI: 10.1017/age.2016.6.

Moreo, A, Woods, R., Simmons, G. and Bergman, C. (2019), "Connection or competence: Emotional labor and service quality's impact on satisfaction and loyalty", International Journal of Contemporary Hospitality Management, Vol. 31 No. 2, pp. 1-19.DOI: 10.1108/IJCHM-03-2017-0176.

Nassivera, F. and Sillani, S. (2015), "Consumer perceptions and motivations in choice of minimally processed vegetables a case study in Italy”, British Food Journal, Vol. 117 No. 3, pp. 970-986. DOI: 10.1108/BFJ-032014-0132.

Nicholls, A.J. (2002), "Strategic options in fair trade retailing", International Journal of Retail \& Distribution Management, Vol. 30 No. 1, pp. 6-17. DOI: 10.1108/09590550210415220.

Oliver, R.L. (1999), “Whence consumer loyalty?”, Journal of Marketing, Vol. 63, pp. 33-44. DOI: $10.2307 / 1252099$.

Pan, Y. and Zinkhan, G.M. (2006), "Determinants of retail patronage: a meta-analytical perspective", Journal of Retailing, Vol. 82 No.3, pp. 229-243. DOI: 10.1016/j.jretai.2005.11.008.

Parasuraman, A. Zeithaml, V.A. and Berry, L.L. (1988), "SERQUAL: a multiple-item scale for measuring consumer perceptions of service quality”, Journal of Retailing, Vol. 64 No. 1, pp. 12-40. DOI: 10.1016/S01482963(99)00084-3.

Parker, C.J. and Wenyu, L. (2019), "What influences chinese fashion retail? Shopping motivations, demographics and spending", Journal of Fashion Marketing and Management, Vol. 23 No. 2, pp. 158-175. DOI: 10.1108/JFMM-09-2017-0093.

Podsakoff, P.M., MacKenzie, S.B., Lee, J. and Podsakoff, N.P. (2003), "Common method bias in behavioral research: a critical review of the literature and recommended remedies", Journal of Applied Psychology, Vol. 88, No. 5, pp. 879-903.

Prebensen, N.K. and Xie, J. (2017), "Efficacy of co-creation and mastering on perceived value and satisfaction in tourists' consumption”, Tourism Management, Vol. 60, pp. 166-176. DOI: 10.1016/j.tourman.2016.12.001.

Rahman, M.S., Zaman, M.H., Hassan, H. and Wei, C.C. (2018), "Tourist's preferences in selection of local food: perception and behavior embedded model", Tourism Review, Vol. 73 No. 1, pp. 111-132. DOI: 10.1108/TR-04-2017-0079

Rauyruen, P. and Miller, K. E. (2007), "Relationship quality as a predictor of B2B customer loyalty”, Journal of Business Research, Vol. 60 No. 1, pp. 21-31. DOI: 10.1016/j.jbusres.2005.11.006.

Rezaei, S., Amin, M. and Ismail, W.K. (2014), "Online repatronage intention: an empirical study among Malaysian experienced online shoppers", International Journal of Retail \& Distribution Management, Vol. 42 No. 5, pp. 390-421. DOI: 10.1108/IJRDM-03-2012-0026.

Sánchez, J., Callarisa, L.J., Rodríguez, R.M. and Moliner, M.A. (2006), "Perceived value of the purchase of a tourism product", Tourism Management, Vol. 27 No. 3, pp. 394-409. DOI: 10.1016/j.tourman.2004.11.007. 
Schiffman, L., Cass, A., Paladino, A., Alessandro, S. and Bednall, D. (2012), Consumer Behavior, Pearson Hall, Australia.

Schoolman, E.D. (2016), "Completing the circuit: routine, reflection, and ethical consumption", Sociological Forum, Vol. 31 No. 3, pp. 619-641. DOI: 10.1111/socf.12266.

Singh, D.P. (2018), "Integration of materialism with shopping motivations: motivations based profile of Indian mall shoppers", Journal of Asia Business Studies, Vol. 12 No. 4, pp. 381-401. DOI: 10.1108/JABS-05-20160075 .

Solomon, M.R. (2015), Consumer behavior: buying, having, being, Pearson, UK.

Sramova, B. and Pavelka, J. (2019), "Gender differences and wellbeing values in adolescent online shopping", International Journal of Retail \& Distribution Management, Vol. 47 No. 6, pp. 623-642. DOI: 10.1108/IJRDM-08-2017-0173.

Sweeney, J.C. and Soutar, G.N. (2001), "Consumer perceived value: the development of a multiple item scale", Journal of Retailing, Vol. 77 No. 2, pp. 203-220. DOI: 10.1016/S0022-4359(01)00041-0.

Vajarodaya, C. and Fernando, M.S.C.L. (2017), "Factors influencing purchase intention towards a retail clothing company", International Research E-Journal on Business and Economics, Vol. 3 No. 1, pp. 43-51.

Wang, C.L., Dongjin L., Bradley R.B. and Jongseok, A. (2012), "Country image, product image and consumer purchase intention: evidence from an emerging economy", International Business Review, Vol. 21 No. 6, pp. 1041-1051. DOI: 10.1016/j.ibusrev.2011.11.010.

Wang, E.S.T (2013), "The influence of visual packaging design on perceived food product quality, value, and brand preference", International Journal of Retail \& Distribution Management, Vol. 41 No. 10, pp. 805-816. DOI: 10.1108/IJRDM-12-2012-0113.

Wang, E.S.T. (2017), "Different effects of utilitarian and hedonic benefits of retail food packaging on perceived product quality and purchase intention", Journal of Food Products Marketing, Vol. 3 No. 3, pp. 239-250. DOI: 10.1080/10454446.2014.885867.

Wu, S.I. and Chen, Y.J. (2014), "The impact of green marketing and perceived innovation on purchase intention for green products", International Journal of Marketing Studies, Vol. 6 No. 5, pp. 81-100. DOI: 10.5539/ijms.v6n5p81. 
Figure 1 - Theoretical framework

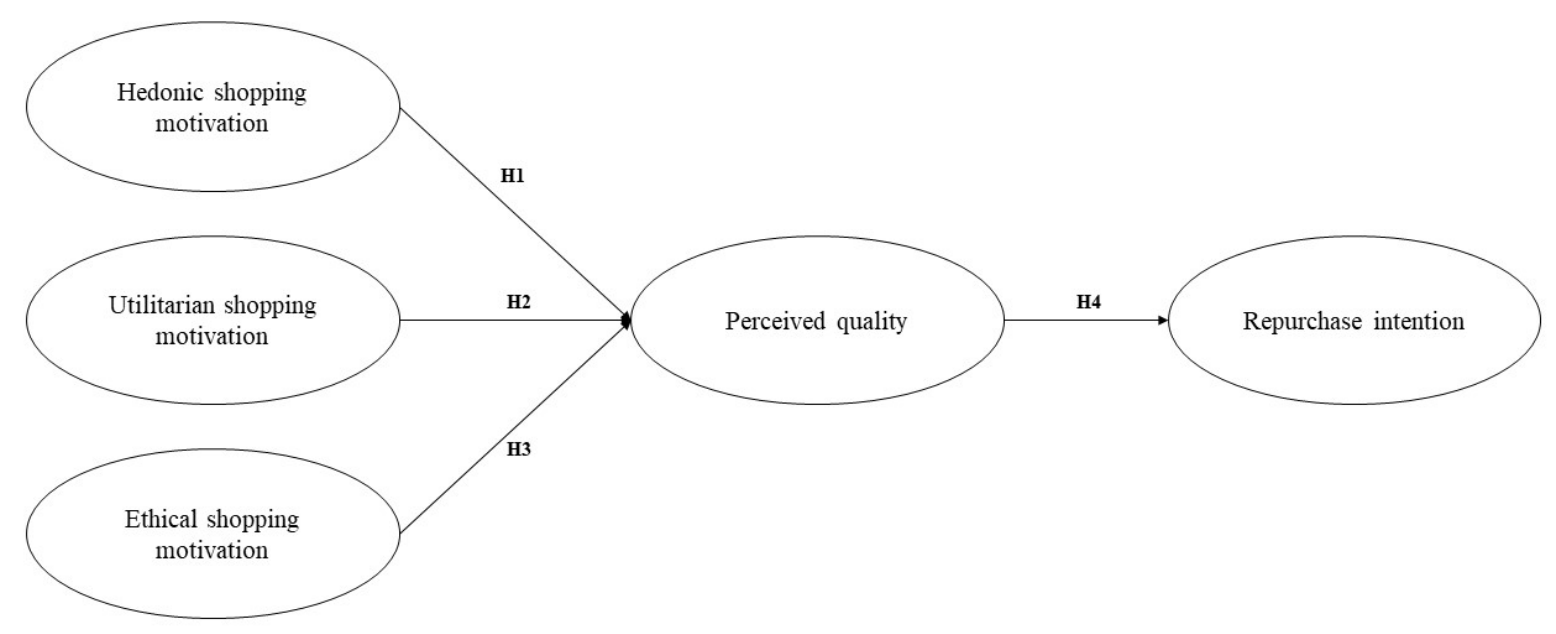


Table 1. Profile of respondents

\begin{tabular}{|c|c|c|}
\hline Variable & Frequency & Percentage \\
\hline \multicolumn{3}{|l|}{ Gender } \\
\hline Male & 104 & 48.8 \\
\hline Female & 109 & 51.2 \\
\hline \multicolumn{3}{|l|}{ Age in years } \\
\hline $18-24$ & 15 & 7.0 \\
\hline $25-34$ & 43 & 20.2 \\
\hline $35-44$ & 43 & 20.2 \\
\hline $45-54$ & 43 & 20.2 \\
\hline $55-64$ & 25 & 11.7 \\
\hline 65 and above & 44 & 20.7 \\
\hline \multicolumn{3}{|l|}{ Education } \\
\hline Primary school & 27 & 12.6 \\
\hline High school/Technical school & 100 & 46.9 \\
\hline University and above & 86 & 40.4 \\
\hline \multicolumn{3}{|l|}{ Monthly household income in euros } \\
\hline $0-1,000$ & 43 & 20.2 \\
\hline $1,001-1,500$ & 87 & 40.8 \\
\hline $1,501-2,500$ & 67 & 31.5 \\
\hline 2,501 and above & 16 & 7.5 \\
\hline \multicolumn{3}{|l|}{ Occupation } \\
\hline Student & 27 & 12.7 \\
\hline Employed & 114 & 53.5 \\
\hline Homemaking & 18 & 8.5 \\
\hline Unemployed & 43 & 20.2 \\
\hline Retired & 11 & 5.2 \\
\hline
\end{tabular}

Note: $n=213$

Table 2. Analysis of scale dimensionality, reliability and validity (Fully standardized solution).

\begin{tabular}{|l|l|l|}
\hline \multicolumn{1}{|c|}{ Items } & \multicolumn{1}{|c|}{$\begin{array}{c}\text { Factor } \\
\text { loading }\end{array}$} & t-Value \\
\hline Hedonic shopping motivation (CR=.84; AVE=.67) & & \\
\hline I consider shopping a way to enjoy and escape from the daily stress. & .76 & $10.45^{* *}$ \\
\hline I love to shop with my family or friends. & .70 & Fixed \\
\hline I really like to keep up with fashion and new trends. & .91 & $11.40^{* *}$ \\
\hline Utilitarian shopping motivation (CR=.92; AVE=.82) & & Fixed \\
\hline $\begin{array}{l}\text { I like to feel that I have achieved what I had planned for that shopping } \\
\text { trip. }\end{array}$ & .96 & $13.15^{* *}$ \\
\hline I feel satisfied after buying everything I wanted. & .88 & $14.71^{* *}$ \\
\hline $\begin{array}{l}\text { I value being able to get good opportunities in terms of value for } \\
\text { money. }\end{array}$ & .84 & Fixed \\
\hline Ethical shopping motivation (CR=.88; AVE=.75) & & $14.84^{* *}$ \\
\hline $\begin{array}{l}\text { With the completion of my purchase I felt that I was contributing to the } \\
\text { local economy. }\end{array}$ & .84 & $14.69^{* *}$ \\
\hline I value the moral behavior of small retailers. & .85 & .84 \\
\hline Shopping at small retailers I feel that I am doing the right thing. & & \\
\hline
\end{tabular}




\begin{tabular}{|l|l|l|}
\hline Perceived quality $(\mathbf{C R}=\mathbf{. 8 7} \mathbf{A V E}=\mathbf{. 6 8})$ & & \\
\hline The service that I have been given as a whole has been correct. & .87 & Fixed \\
\hline $\begin{array}{l}\text { They offer an acceptable level of quality when compared to other } \\
\text { stores. }\end{array}$ & .81 & $11.82^{* *}$ \\
\hline The service received is what I expected. & .75 & $10.86^{* *}$ \\
\hline I am satisfied with the service quality. & .72 & $10.66^{* *}$ \\
\hline Repurchase intention $(\mathbf{C R = . 8 7 ;} \mathbf{A V E}=. \mathbf{7 3})$ & & \\
\hline I will try to keep shopping at small retailers in the next few years. & .87 & Fixed \\
\hline As long as they treat me like they do now, I doubt I change center type. & .82 & $14.14^{* *}$ \\
\hline I try to visit small retailers every time I need or want to go shopping. & .81 & $14.02^{* *}$ \\
\hline
\end{tabular}

Note: Fit of the model: $\chi^{2}=87.94, \mathrm{df}=73, \mathrm{P}=.11207$; RMSEA=.031; CFI $=.99 ; \mathrm{NFI}=.98 ; \mathrm{NNFI}=.99$. $\mathrm{CR}=$ composite reliability; $\mathrm{AVE}=$ average variance extracted $(* * p<.01)$

Table 3. Discriminant validity of the scale

\begin{tabular}{|l|c|c|c|c|c|}
\hline & 1 & 2 & 3 & 4 & 5 \\
\hline 1. Hedonic shopping motivation & .82 & & & & \\
\hline 2. Utilitarian shopping motivation & .03 & .91 & & & \\
\hline 3.Ethical shopping motivation & .51 & .28 & .86 & & \\
\hline 4. Perceived quality & .53 & .24 & .57 & .83 & \\
\hline 5. Repurchase intention & .51 & .33 & .33 & .65 & .86 \\
\hline
\end{tabular}

Below the diagonal: correlation estimated between the factors.

Diagonal: square root of AVE.

Table 4. Results of the structural model

\begin{tabular}{|c|l|c|c|c|}
\hline $\begin{array}{c}\text { Hypothesi } \\
\mathrm{s}\end{array}$ & \multicolumn{1}{|c|}{ Path } & $\begin{array}{c}\text { Paramete } \\
\mathrm{r}\end{array}$ & t-Value & Results \\
\hline $\mathrm{H}_{1}$ & $\begin{array}{l}\text { Hedonic shopping motivation } \rightarrow \\
\text { Perceived quality }\end{array}$ & .22 & 3.97 & Supported \\
\hline $\mathrm{H}_{2}$ & $\begin{array}{l}\text { Utilitarian shopping motivation } \rightarrow \\
\text { Perceived quality }\end{array}$ & .34 & 6.37 & Supported \\
\hline $\mathrm{H}_{3}$ & $\begin{array}{l}\text { Ethical shopping motivation } \rightarrow \text { Perceived } \\
\text { quality }\end{array}$ & .46 & 7.61 & Supported \\
\hline $\mathrm{H}_{4}$ & Perceived quality $\rightarrow$ Repurchase intention & .88 & 11.00 & Supported \\
\hline
\end{tabular}

Note: Fit of the model: $\chi^{2}=14.75 ; \mathrm{df}=9, \mathrm{P}=0.09800 ; \mathrm{RMSEA}=0.055 ; \mathrm{CFI}=0.98 ; \mathrm{NFI}=0.95$; $\mathrm{NNFI}=0.98$. 
Table 5. Total and indirect effects

\begin{tabular}{|c|l|c|c|}
\hline & \multicolumn{3}{|c|}{ EFFECTS } \\
\hline \multirow{4}{*}{ ANTECEDENTS } & & Perceived Quality & Repurchase Intention \\
\cline { 2 - 4 } & Hedonic shopping motivation & .22 & $.19(.19)$ \\
\cline { 2 - 4 } & Utilitarian shopping motivation & .34 & $.30(.30)$ \\
\cline { 2 - 4 } & Ethical shopping motivation & .46 & $.41(.41)$ \\
\cline { 2 - 5 } & Perceived quality & -- & .88 \\
\hline
\end{tabular}

